Danijela Despotović ${ }^{1}$ Slobodan Cvetanović ${ }^{2}$ Vladimir Nedić ${ }^{3}$
JEL: 030, 011

DOI: 10.5937/industrija42-4602

UDK: $330.341 .1 ; 338: 339.137 .2$

(497-15)

Original Scientific Paper

\title{
Innovativeness and Competitiveness of the Western Balkan Countries and Selected EU Member States
}

\author{
Article history: \\ Received: 7 October 2013 \\ Sent for revision: 21 October 2013 \\ Received in revised form: 26 November 2013 \\ Accepted: 6 December 2013 \\ Available online: 28 March 2014
}

\begin{abstract}
Given that innovativeness stands for one of the most significant categories in the process of investigating key economic phenomena, including competitiveness of economy, the paper will: a) explain the metrics of The Global Innovation Index and The Global Competitiveness Index, as two undoubtedly most significant analytical frameworks for expressing the achieved level and key determinants of innovativeness, on the one hand, and the factors of countries' competitiveness at the global level, on the other hand, and b) provide empirical analysis of the correlation between innovativeness and competitiveness of the Western Balkan countries (Albania, Bosnia and Herzegovina, Macedonia, Serbia, Croatia, and Montenegro), the European Union member states from the region (Austria, Bulgaria, Greece, Hungary, Romania and Slovenia). After applying the adequate methodology, a conclusion was made that: a) Western Balkan countries lag behind the European Union member states in the level of innovativeness, and $b$ ) from the aspect of correlation between innovativeness and countries' competitiveness, statistically significant correlation has not been determined for the Western Balkan countries, unlike selected EU member states where a strong linear correlation between these variables has been determined in 2012.
\end{abstract}

Key words: The Western Balkans, the Global Innovation Index, the Global Competitiveness Index.

\footnotetext{
${ }^{1}$ University of Kragujevac, Faculty of Economics, Serbia, ddespotovic@kg.ac.rs

${ }^{2}$ University of Niš, Faculty of Economics, Serbia

${ }^{3}$ University of Kragujevac, Faculty of Philology and Arts, Serbia
} 
Despotović D. et al.: Innovativeness and Competitiveness of the Western Balkan...

\section{Inovativnost i konkurentnost zemalja Zapadnog Balkana i selektovanih zemalja EU}

Apstrakt: Polazeći od stava da kompleks inovativnosti predstavlja jednu od najznačajnijih tema $u$ istraživanju mnogih ekonomskih fenomena, uključujući $i$ konkurentnost privrede, u radu je data: a) eksplikacija metrike Indeksa globalne inovativnosti i Indeksa globalne konkurentnosti, kao nesumnjivo dva najznačajnija analitička okvira za iskazivanje dostignutog nivoa i ključnih determinanti inovativnosti privrede, $s$ jedne, $i$ faktora konkurentnosti zemlje $u$ svetskim relacijama, $s$ druge strane $i$ b) empirijska analiza međuzavisnosti inovativnosti i konkurentnosti zemalja Zapadnog Balkana (Albanija, Bosna $i$ Hercegovina, Makedonija, Srbija, Hrvatska i Crna Gora) i država Evropske unije koje okružuju ovaj region (Austrija, Bugarska, Grčka, Mađarska, Rumunija $i$ Slovenija). Primenom odgovarajuće metodologije došlo se do zaključka da a) zemlje Zapadnog Balkana znatno zaostaju u nivou inovativnosti za selektovanim državama Evropske unije $i$ b) da u razmatranju veze, sa aspekta stepena medjuzavisnosti inovativnosti $i$ nacionalne konkurentnosti, za zemlje Zapadnog Balkana nije detektovana statistički značajna korelacija, za razliku od selektovanih zemalja EU gde je ustanovljeno postojanje jake linearne korelacije ovih varijabli u 2012.

Ključne reči: Zapadni Balkan, Indeks globalne inovativnosti, Indeks globalne konkurentnosti.

\section{Introductory notes}

Innovativeness of an economy is reflected in country's ability to produce and commercialize goods and services by using new knowledge and skills (Porter \& Stern, 2002). It focuses on country's potential to create, improve and use innovations with the purpose of generating economic value (Cvetanović, Mladenović \& Nikolić, 2011). Strengthening innovativeness is the key precondition of economic growth (Link \& Siegel, 2003; Sener \& Sarıdogan, 2011; Hasan \& Tucci, 2010).

Innovativeness of economy is quantified by using a number of composite indices. The Global Innovation Index (GII), the Innovation Union Scoreboard, the Global Cleantech Innovation Index and the Global Innovation Policy Index are given special significance.

The Global Innovation Index, as the most frequently used indicator of the achieved level of innovativeness at the global level, will be used for analyzing innovativeness of the Western Balkan economies in this paper. Inspired by the latest innovation-driven research, the GII model for 2012 was based on the previous editions of the index and accompanied with the latest data. It 
Despotović D. et al.: Innovativeness and Competitiveness of the Western Balkan...

included 141 countries representing $94.9 \%$ of the world population and $99.4 \%$ of the world GDP.

Competitiveness has become a popular research subject in the field of economics (Zubović \& Bradić-Martinović, 2013). This was to be expected due to the fact that in the last thirty years competitiveness was continuously at the top of the list of macroeconomic policy goals in the majority of world countries. However, there is still no generally accepted definition of country's competitiveness (Marginean, 2006). What is more, as some authors claim, the concept of macro-competitiveness does not exist, which implies that it is not logical to think about macroeconomic policy based on such concept (Krugman, 1994, 1996).

Irrespective of the controversies hiding behind the reality of the concept of competitiveness, it is estimated that there are more than a hundred different forms of indicators for quantifying this phenomenon. Some of them have a long tradition, therefore attracting attention of the world community and exerting significant impact on other socio-economic trends. Others are less important and have an impact on particular fields only. The Global Competitiveness Index, published by the World Economic Forum, will be used for analyzing the countries' competitiveness in this paper.

Global competition is faced with significant changes on the global map of capacity to create new knowledge (Stefanović, 2011; Cvetanović, Despotović \& Nedić, 2012; Krstić \& Stanišić, 2013). The need to remain competitive on the world market has become especially important during the period of crisis (Cvetanović, Mladenović \& Despotović, 2012). Special focus is placed on innovations which are seen as the most important source of sustainable economic growth (Welfens, 2011).

Starting from the thesis that innovativeness of economy represents the key determinant in the improvement of country's competitiveness (Gibson \& Naquin, 2011), the research, on which this paper is based, aims to establish the extent to which the competitiveness of selected countries relies on using their innovative potential (Metcalfe \& Ramlogan, 2008), in order to point out the existence of differences between them, as well as show the differences in level of innovativeness achieved by observed groups of countries.

The first part of the paper will explain the structure of these two composite indices. After that, data stemming from these indices for 2012 will serve as the basis for focusing empirical research on the comparative analysis of the most significant innovation performances and competitiveness of the Western Balkan countries, the EU member states from the region and the EU as a whole (Almunia, 2010). Special part of the paper will focus on the study of innovativeness as the factor of competitiveness of the selected groups of countries. 
Despotović D. et al.: Innovativeness and Competitiveness of the Western Balkan...

The analysis included the countries from:

- the Western Balkans (Albania, Macedonia, Montenegro, Croatia ${ }^{4}$, Bosnia and Herzegovina and Serbia),

- the EU member states surrounding the Western Balkan countries (Austria, Slovenia, Bulgaria, Hungary, Romania and Greece) and

- the European Union.

This provided the reference frame for comparing and evaluating the indices of innovativeness and competitiveness of the Western Balkan countries. It was implicitly assumed that in case the comparative analysis of key innovativeness parameters showed enormous gap among the Western Balkan countries and the selected EU member states from the region with respect to the level of innovativeness, the intensity of the Western Balkans's transition to the market economic model would not ensure its economic convergence with more developed EU neighbours. Prior to the dissolution of the former socialist economic model, these countries, except for Greece and Austria, had functioned in accordance with more or less the same economic system. Hungary and Slovenia joined the EU during its fifth enlargement in 2004, whereas Bulgaria and Romania joined the European family during its sixth enlargement in 2007.

\section{Metrics of economy's innovativeness and country's competitiveness}

Measuring of global innovativeness was initiated by the international business school INSEAD in 2007. Initially, the focus was on modernizing the existent model of quantifying innovativeness and overcoming the traditional way of expressing innovativeness by the number of patents, number of published scholarly articles or the share of research and development activity costs in gross domestic product. Since 2012, INSEAD and World Intellectual Property Organization have been engaging in joint efforts to analyze The Global Innovation Index. The results of their analyses are available to 141 countries. The Global Innovation Index relies on two sub-indices, the innovation input sub-index and the innovation output sub-index. It is expressed in the form of 0-100 score ranking. Innovation inputs include elements that enable innovative activities. These elements are classified into five groups: 1) institutions, 2) human capital and research, 3) infrastructure, 4) market sophistication, and 5) business sophistication. Innovation outputs consist of two pillars that point to actual innovation results: 6) knowledge and science output, and 7) creative output (Figure 1).

${ }^{4}$ On 1 July 2013, Croatia became a full-fledged member of the European Union 
Despotović D. et al.: Innovativeness and Competitiveness of the Western Balkan...

Figure 1. Structure Global Innovation index

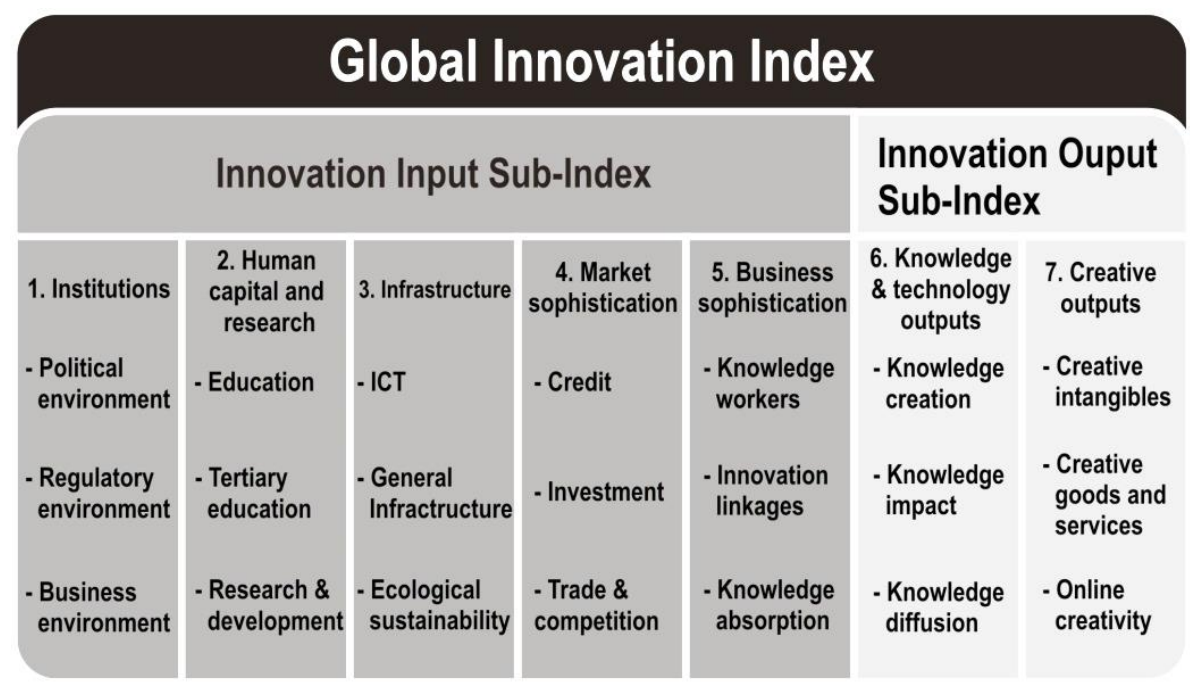

Source: Modified according to: The Global Innovation Index, INSEAD \& WIPO, 2012.

Methodology for calculating The Global Innovation Index relies on the studies, such as The European Foundation for Quality Management (EFQM) Excellence Model and the Global Competitiveness Report (GCR) of the World Economic Forum.

There is still no unique methodology for measuring country's competitiveness. Practice has shown the existence of several methodological tools for measuring competitiveness. World Economic Forum is the only one that uses the term competitiveness in its Global Competitiveness Report. Non-existence of a unique quantitative measure of this economic phenomenon hinders the development of the concept of macro-competitiveness.

The Global Competitiveness Index is very complex and rests on the analysis and evaluation of 12 pillars of competitiveness that give an all-encompassing picture of a country's level of competitiveness (Figure 2). 
Figure 2. Structure Global Competitiveness Index

\begin{tabular}{|c|c|c|}
\hline $\begin{array}{c}\text { Basic } \\
\text { requirements }\end{array}$ & $\begin{array}{l}\text { Efficiency } \\
\text { enhancers }\end{array}$ & $\begin{array}{c}\text { Innovation and } \\
\text { sophistication factors }\end{array}$ \\
\hline \multirow{2}{*}{ 1. Institutions } & \multirow{2}{*}{$\begin{array}{l}\text { 5. Higher education } \\
\text { and training }\end{array}$} & 11.Busines sophistication \\
\hline & & 12 .INNOVATION \\
\hline 2. Infrastructure & 6. Goods market efficiency & - Capacity for innovation \\
\hline \multirow{2}{*}{$\begin{array}{l}\text { 3. Macroeconomic } \\
\text { environment }\end{array}$} & \multirow{2}{*}{$\begin{array}{l}\text { 7. Labor market efficiency } \\
\text { 8. Financial market } \\
\text { development }\end{array}$} & $\begin{array}{l}\text { - Quality of } \\
\text { scienttfic research } \\
\text { institutions }\end{array}$ \\
\hline & & \\
\hline \multirow{4}{*}{$\begin{array}{l}\text { 4. Health and } \\
\text { primary education }\end{array}$} & Tevelopilit & $\begin{array}{l}\text { - University-industry } \\
\text { collaboration }\end{array}$ \\
\hline & $\begin{array}{l}\text { 9. Technological readiness } \\
\text { 10. Market size }\end{array}$ & $\begin{array}{l}\text { - Gov't procurement } \\
\text { of advanced } \\
\text { tech products }\end{array}$ \\
\hline & & $\begin{array}{l}\text { - Availability of } \\
\text { scientists and } \\
\text { engineers }\end{array}$ \\
\hline & & $\begin{array}{l}\text { - PCT patents, } \\
\text { applications/million pop. }\end{array}$ \\
\hline
\end{tabular}

Source: Modified according to: Global Competitiveness Report 2012-2013, World Economic Forum, 2012.

Figure 2 shows that the twelfth pillar deals with innovativeness as the factor of competitiveness consisting of the following seven sub-pillars: a) capacity for innovation, b) quality of scientific research institutions, c) the number of registered patents per one million people, d) government procurement of advanced technological products, e) university-industry collaboration in the field of research and development, f) availability of engineers and scientists, and g) enterprises' investments in research and development.

\section{Innovativeness and competitiveness of the Western Balkan countries and the selected European Union member states - variable analysis by data visualization}

This research evaluates innovativeness by using the data presented in The Global Innovation Report, INSEAD, 2012. Figure 3 shows innovation index, innovation outputs and innovation inputs of two groups of selected countries and the EU27 as a whole. The level of global innovation index shows that Austria was at a considerable disadvantage compared with the EU27 in 2012. 
Despotović D. et al.: Innovativeness and Competitiveness of the Western Balkan...

In the same period, Slovenia and Hungary were at an average disadvantage, whereas all other observed countries were at $7-15 \%$ disadvantage compared with the EU27. In addition, the Western Balkan countries were at a disadvantage of approximately $7 \%$ compared with the group of six EU member states from their neighbourhood.

Figure 3. Global Innovation index, Innovation Output Sub-Index and Innovation Input Sub-Index

\section{$\square$ GII $\square$ Innovation Output Sub-Index $\quad$ Innovation Input Sub-Index}

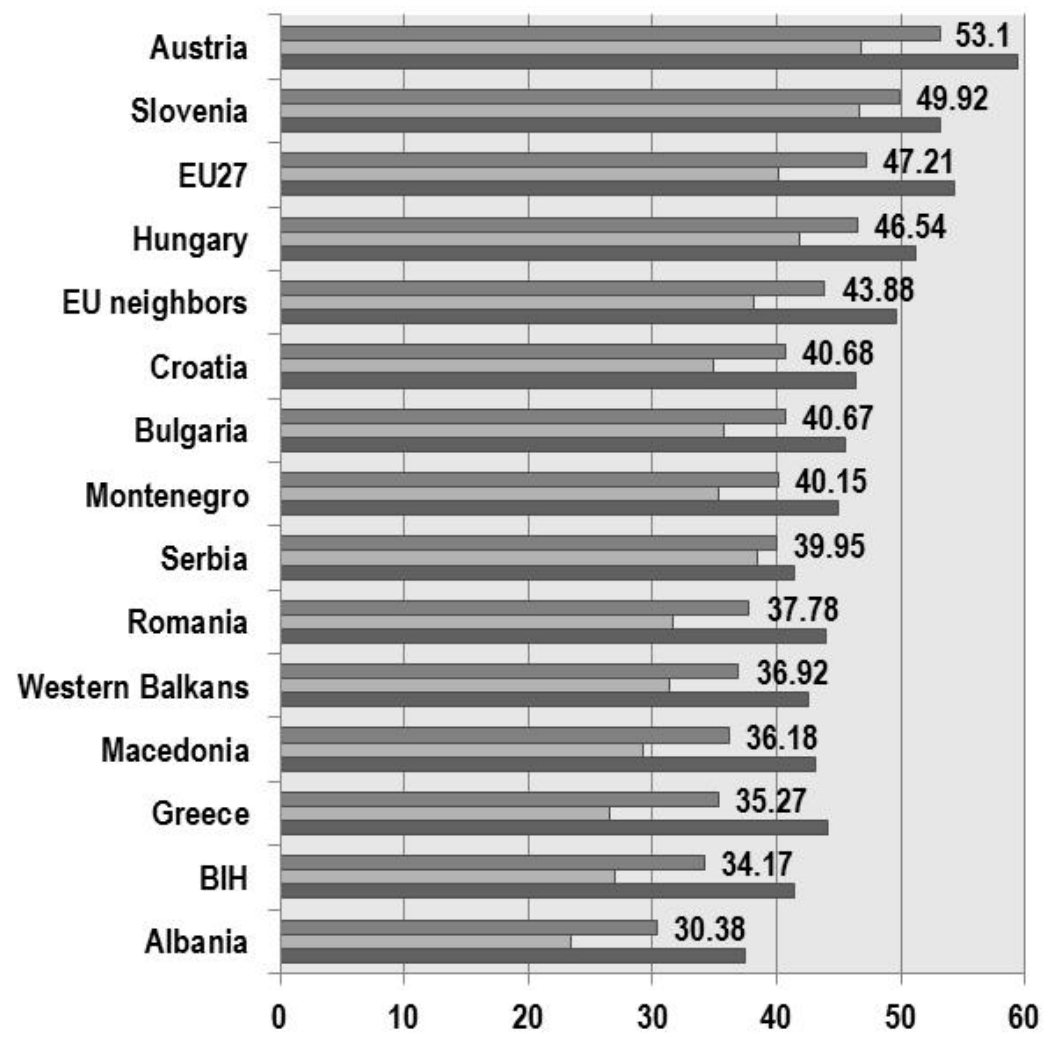

Source: The Global Innovation Index, INSEAD \& WIPO, 2012.

With the purpose of understanding the source of these significant differences, all seven categories which are used for calculating the global innovation index will be compared. Table 1 gives an overview of global innovation index and its 
Despotović D. et al.: Innovativeness and Competitiveness of the Western Balkan...

basic components with respect to the selected countries and EU27 as a whole.

Table 1. Global innovation index for selected country groups - Score (0-100)

\begin{tabular}{|c|c|c|c|c|c|c|c|c|c|c|}
\hline Country & GII & $\begin{array}{c}\text { Innovatio } \\
n \text { Input } \\
\text { Sub- } \\
\text { Index }\end{array}$ & $\begin{array}{l}\text { Innovation } \\
\text { Output } \\
\text { Sub-Index }\end{array}$ & 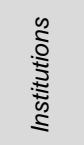 & $\begin{array}{l}\text { Human } \\
\text { capital } \\
\text { and } \\
\text { research }\end{array}$ & 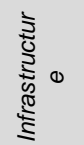 & 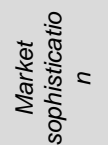 & 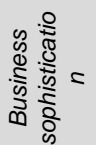 & $\begin{array}{c}\text { Knowledg } \\
\text { e \& } \\
\text { technolog } \\
\text { y outputs }\end{array}$ & $\begin{array}{c}\text { Creativ } \\
e \\
\text { output } \\
s\end{array}$ \\
\hline Albania & 30.4 & 37.4 & 23.4 & 55.0 & 26.2 & 33.6 & 49.7 & 22.6 & 18.6 & 28.2 \\
\hline $\mathrm{BIH}$ & 34.2 & 41.4 & 26.9 & 51.4 & 41.6 & 28.9 & 41.2 & 44.2 & 25.9 & 27.9 \\
\hline Macedonia & 36.2 & 43.2 & 29.2 & 68.8 & 36.6 & 35.2 & 43.1 & 32.2 & 28.8 & 29.6 \\
\hline Serbia & 40.0 & 41.5 & 38.5 & 56.0 & 43.1 & 35.1 & 36.7 & 36.3 & 40.1 & 36.9 \\
\hline $\begin{array}{l}\text { Montenegr } \\
0\end{array}$ & 40.2 & 45.0 & 35.3 & 58.5 & 49.3 & 34.0 & 44.8 & 38.4 & 26.0 & 44.6 \\
\hline Croatia & 40.7 & 46.4 & 34.9 & 69.2 & 41.9 & 44.9 & 36.8 & 39.4 & 34.0 & 35.8 \\
\hline \begin{tabular}{|l} 
Western \\
Balkans
\end{tabular} & 36.9 & 42.5 & 1.4 & 59.8 & 39.8 & 35.2 & 42.1 & 35.5 & 32.7 & 3.8 \\
\hline Greece & 35.3 & 44.0 & 26.5 & 60.7 & 45.6 & 43.2 & 34.8 & 35.8 & 25.6 & 27.5 \\
\hline Romania & 37.8 & 43.9 & 31.7 & 62.1 & 36.1 & 44.3 & 39.7 & 37.4 & 34.0 & 29.3 \\
\hline Bulgaria & 40.7 & 45.6 & 35.8 & 67.2 & 39.9 & 41.2 & 42.6 & 36.8 & 35.7 & 35.9 \\
\hline Hungary & 46.5 & 51.2 & 41.9 & 72.3 & 46.0 & 48.5 & 42.2 & 46.9 & 46.8 & 37.0 \\
\hline Slovenia & 49.9 & 53.2 & 46.6 & 78.0 & 51.5 & 47.8 & 40.9 & 47.9 & 41.7 & 51.5 \\
\hline Austria & 53.1 & 59.5 & 46.8 & 82.3 & 58.9 & 53.4 & 51.8 & 50.9 & 41.4 & 52.1 \\
\hline \begin{tabular}{|l|}
$E U$ \\
neighbours \\
\end{tabular} & 43.9 & 49.6 & 38.2 & 70.4 & 46.3 & 46.4 & 42.0 & 42.6 & 33.7 & 38.9 \\
\hline EU27 & 47.2 & 54.3 & 40.1 & 81.0 & 50.8 & 38.6 & 51.8 & 49.4 & 37.9 & 42.4 \\
\hline
\end{tabular}

Source: The Global Innovation Index, INSEAD \& WIPO, 2012.

The Western Balkan countries are at a considerable disadvantage compared with six selected EU member states from their neighbourhood with respect to all pillars of global innovation index. The fourth innovation input sub-pillar (Market sophistication) and the sixth innovation input sub-pillar (Knowledge and technology outputs) are an exception due to the fact that the Western Balkan countries approached the average of the selected EU member states with respect to these sub-pillars. The most significant differences, on the input side, are seen in the categories Institutions, Infrastructure and Business sophistication. Taking into consideration that the category Institutions focuses on political stability and the rule of law and the category Infrastructure involves general and information and communication infrastructure, it can be stated that these differences could be expected. Political instability and current internal affairs, lack of basic institutions and inefficiency of legal system, particularly in the field of protecting intellectual property, are the 
Despotović D. et al.: Innovativeness and Competitiveness of the Western Balkan...

characteristics of this region. What is more, insufficient development of general and information and communication infrastructure is another indicator of the unfavourable situation, which is even worsened if it is compared to the average of EU27. In that case, the differences are even more pronounced. Figure 4 shows the correlation between the observed variables. The observed characteristics per individual countries are determined as the average of the results that two groups of selected countries achieved according to individual indicators of competitiveness and innovativeness.

Figure 4. Graphic presentation of the relations among the observed variables of the Global Innovation Index

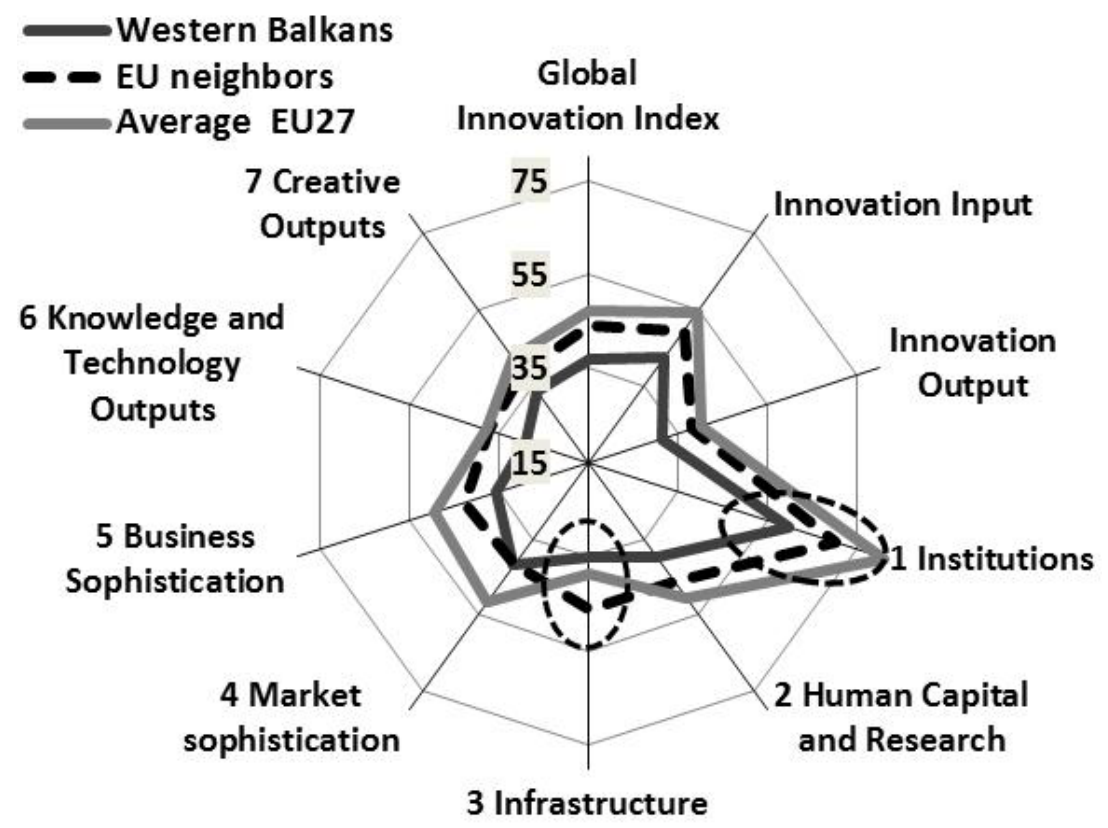

Source: Author

The analysis of innovative performances of the observed groups of countries shows that the EU membership does not guarantee the satisfactory level of innovativeness. This fact can be exemplified by Greece, which joined the EU in 1981 and Romania, which joined the EU in 2007. Both countries are characterized by a lower level of innovativeness as compared to Croatia and Montenegro.

The advantages of the EU member states surrounding the Western Balkans are pronounced in the domain of institutions and infrastructure, the fields that 
Despotović D. et al.: Innovativeness and Competitiveness of the Western Balkan...

can be brought into causal relationship with the progress towards the European Union. The Western Balkan countries are characterized by political instability. This is particularly pronounced in Serbia (due to the Kosovo issue), Bosnia and Herzegovina (due to non-functional and non-rational division of the country), and Macedonia (due to the issue of Albania, the naming dispute with Greece, the dispute with Serbia with respect to the church).

Croatia is a leader in the group of the Western Balkan countries. This country also has a mild advantage over two EU member states from the neighbourhood, Romania and Greece. Albania holds the lowest position with respect to innovations and is dealing with the problem in human resources and research and development activities. The bottom position among the EU member states surrounding the Western Balkans is held by Greece. Judging by innovation performances, Serbia represents a moderately innovative country with average performances among the Western Balkan countries. Serbia's relative advantages are reflected in the fields of human resources, research and development and scientific output, whereas its weaknesses are reflected by very moderate share of industry in financing of research and development activities, lack of institutions, and political instability.

Table 2. Global Competitiveness Index, Business sophistication and Innovation

\begin{tabular}{|l|ccc|}
\hline Country & $\begin{array}{c}\text { Global } \\
\text { Competitiveness } \\
\text { Index } \\
\text { Score (1-7) }\end{array}$ & $\begin{array}{c}\text { 11th pillar: } \\
\text { Business } \\
\text { sophistication } \\
\text { Score (1-7) }\end{array}$ & $\begin{array}{c}\text { 12th pillar: } \\
\text { Innovation } \\
\text { Score (1-7) }\end{array}$ \\
\hline Serbia & 3.87 & 3.11 & 2.81 \\
\hline Albania & 3.91 & 3.59 & 2.63 \\
\hline B \& H & 3.93 & 3.48 & 3.09 \\
\hline Croatia & 4.04 & 3.66 & 3.12 \\
\hline Macedonia & 4.04 & 3.44 & 2.83 \\
\hline Montenegro & 4.14 & 3.83 & 3.31 \\
\hline Western Balkans & 3.99 & 3.52 & 2.97 \\
\hline Greece & 3.86 & 3.74 & 3.00 \\
\hline Romania & 4.07 & 3.47 & 2.92 \\
\hline Bulgaria & 4.27 & 3.62 & 2.98 \\
\hline Hungary & 4.30 & 3.74 & 3.61 \\
\hline Slovenia & 4.34 & 4.18 & 3.85 \\
\hline Austria & 5.22 & 5.52 & 3.07 \\
\hline EU neighbours & 4.34 & 4.05 & 4.15 \\
\hline EU27 & 4.74 & 4.61 & \\
\hline
\end{tabular}

Source: Global Competitiveness Report 2012-2013, World Economic Forum. 
Despotović D. et al.: Innovativeness and Competitiveness of the Western Balkan...

Table 2 gives an overview of the global competitiveness index for the observed European countries, particularly the $11^{\text {th }}$ (business sophistication) and the $12^{\text {th }}$ (innovativeness) pillar of competitiveness.

The competitiveness of the Western Balkan countries in the first decade of the $21^{\text {st }}$ century was at relatively low level despite the transition of their economic systems. Main reasons for this should be sought in the nature of political competitiveness occurring in this region at that time. Political instability, corruption and inefficient tax administration were the key problems of strengthening competitiveness during this decade. Appropriate acts did prescribe adequate policies aimed at alleviating these problems. However, during the first decade of the $21^{\text {st }}$ century these policies were not adequately implemented in the form of concrete measures and instruments. Figure 5 gives a comparative view of the correlation between the global competitiveness index by its $11^{\text {th }}$ and $12^{\text {th }}$ pillars and the global innovation index of the Western Balkan countries, the selected EU member states surrounding the Western Balkan countries and the EU27 as a whole.

Figure 5. Graphic presentation of the relations among the observed variables

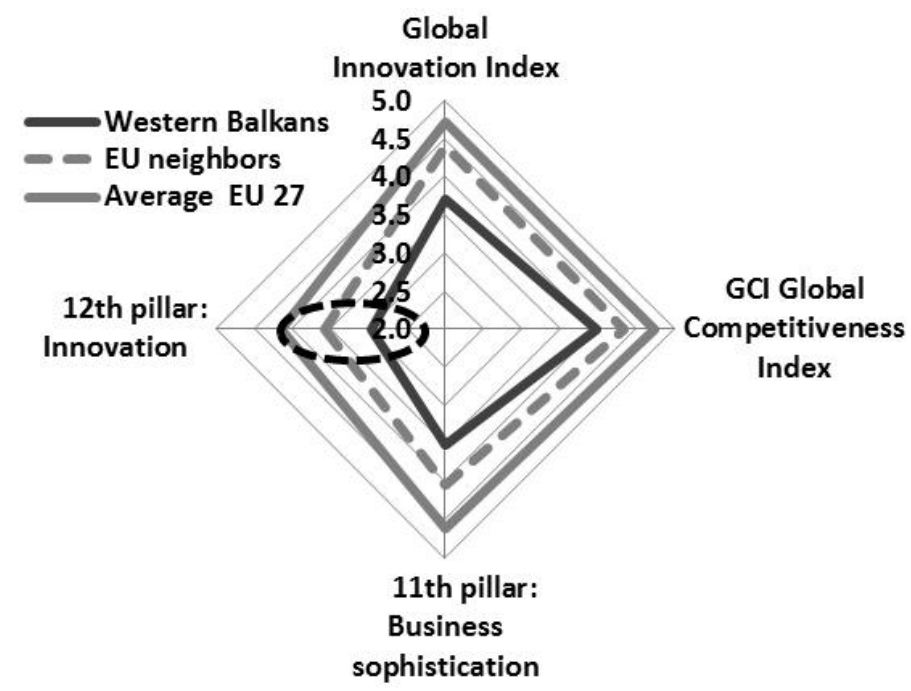

Source: Author

Figure 5 points to the obvious gap among all groups of countries with respect to all indicators.

Table 3 shows the ranking of the observed countries according to the $\mathrm{GCl}$ and its $12^{\text {th }}$ pillar out of the total of 144 countries covered by the GCl Report for the period 2012-2013, as well as the ranking according to the global 
Despotović D. et al.: Innovativeness and Competitiveness of the Western Balkan...

innovation index out of the total of 141 countries covered by The Global Innovation Report for 2012. Judging by the level of the global competitiveness index, Serbia held the lowest position among the Western Balkan countries. According to the same criterion, Greece held the bottom position among the EU member states surrounding the Western Balkans.

With the purpose of making the picture clearer, Figure 6 gives an illustrated overview of the data presented in Table 3.

Table 3. The ranking of the observed countries according to the $\mathrm{GCl}, 12$ th pillar GCl and the GII for 2012

\begin{tabular}{|c|c|c|c|c|c|c|c|}
\hline \multirow{2}{*}{$\begin{array}{c}\text { Country/ } \\
\text { Economy } \\
\text { Western Balkans }\end{array}$} & $\mathrm{GCl}$ & $\begin{array}{c}\text { 12th pillar } \\
\text { Innovatio } \\
n\end{array}$ & GII & \multirow{2}{*}{$\begin{array}{l}\text { Country/ } \\
\text { Economy } \\
\text { Europe } \\
\text { neighbours }\end{array}$} & \multicolumn{3}{|c|}{$\begin{array}{c}\text { 12th pillar } \\
\text { Innovatio } \\
n \\
\end{array}$} \\
\hline & $\begin{array}{c}\text { Rank/ } \\
144 \\
\end{array}$ & $\begin{array}{c}\text { Rank/ } \\
144\end{array}$ & $\begin{array}{c}\text { Rankl } \\
141\end{array}$ & & $\begin{array}{c}\text { Rank/ } \\
144 \\
\end{array}$ & $\begin{array}{c}\text { Rank/ } \\
144 \\
\end{array}$ & $\begin{array}{c}\text { Rank/ } \\
141\end{array}$ \\
\hline Serbia & 95 & 111 & 46 & 1 Austria & 16 & 13 & 22 \\
\hline Albania & 89 & 123 & 90 & 2 Slovenia & 56 & 32 & 26 \\
\hline $\mathrm{B} \& \mathrm{H}$ & 88 & 80 & 72 & 3 Hungary & 60 & 37 & 31 \\
\hline Croatia & 81 & 74 & 42 & 4 Bulgaria & 62 & 92 & 43 \\
\hline Macedonia & 80 & 110 & 62 & 5 Romania & 78 & 102 & 52 \\
\hline Montenegro & 72 & 60 & 45 & 6 Greece & 96 & 87 & 66 \\
\hline
\end{tabular}

Source: Global Competitiveness Report 2012-2013, World Economic Forum and The Global Innovation Index, INSEAD \& WIPO, 2012.

Figure 6. Considered countries rank according to GCA and GII in 2012

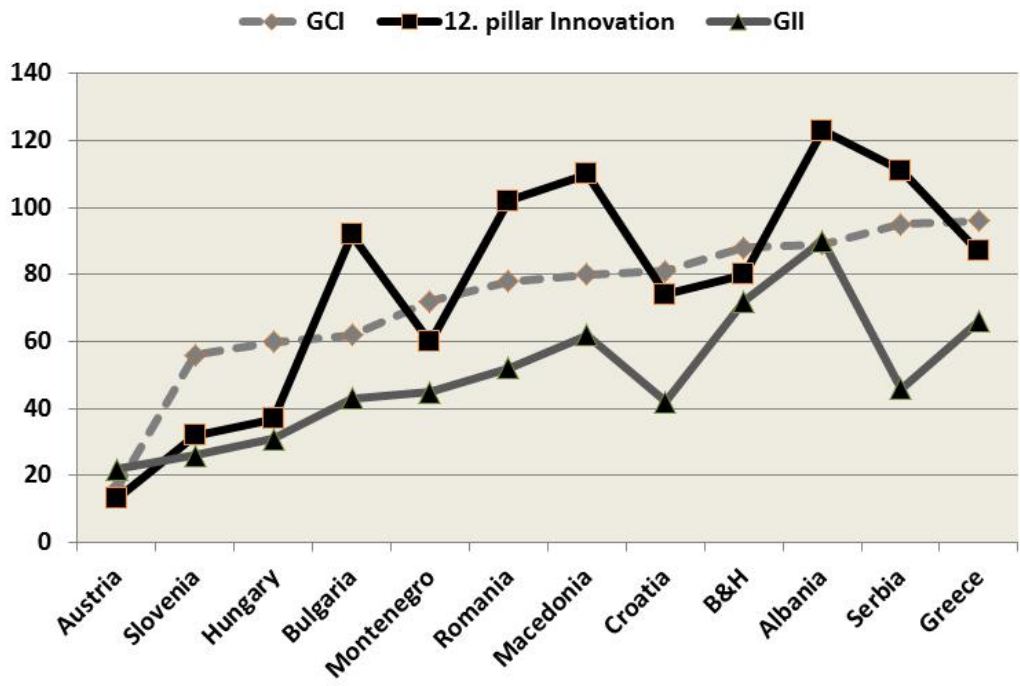

Source: Author 
Despotović D. et al.: Innovativeness and Competitiveness of the Western Balkan...

Judging by the $12^{\text {th }}$ pillar of the Global Competitiveness Index (Innovation) and The Global Innovation Index, it can be seen that there is a certain deviation, i.e. mismatch regarding the ranking of some countries. For example, out of the total of 141 countries, Serbia held the $46^{\text {th }}$ position according to the GII level. Besides, out of the total of 144 countries, it held the $111^{\text {th }}$ position according to the $12^{\text {th }}$ pillar of the Global Competitiveness Index - Innovation. Table 4 gives the value of all observed countries according to all parameters that comprise the $12^{\text {th }}$ pillar (innovation), as well as the average result for all observed groups of countries.

Table 4. The GCl and the 12th pillar of the GCI (Innovation) according to its sub-pillars for the selected groups of countries - Score (0-7)

\begin{tabular}{|c|c|c|c|c|c|c|c|c|}
\hline $\begin{array}{l}\text { Country/ } \\
\text { Economy }\end{array}$ & $\mathrm{GCl}$ & $\begin{array}{c}12.01 \\
\text { Capacity } \\
\text { for } \\
\text { innovation }\end{array}$ & $\begin{array}{l}12.02 \text { Quality } \\
\text { of scientific } \\
\text { research } \\
\text { institutions }\end{array}$ & $\begin{array}{c}12.03 \\
\text { Company } \\
\text { spending } \\
\text { on } R \& D\end{array}$ & $\begin{array}{c}12.04 \\
\text { University- } \\
\text { industry } \\
\text { collaboration } \\
\text { in } R \& D\end{array}$ & $\begin{array}{l}12.05 \text { Gov't } \\
\text { procurement } \\
\text { of advanced } \\
\text { tech products }\end{array}$ & $\begin{array}{c}12.06 \\
\text { Availability } \\
\text { of scientists } \\
\text { and eng. }\end{array}$ & $\begin{array}{l}12.07 \mathrm{PCT} \\
\text { patents, } \\
\text { sapp./million } \\
\text { pop. }\end{array}$ \\
\hline Montenegro & 4.14 & 3.31 & 3.92 & 3.20 & 3.73 & 3.92 & 3.92 & 0.00 \\
\hline Macedonia & 4.04 & 2.80 & 3.22 & 2.53 & 3.17 & 3.18 & 3.53 & 1.54 \\
\hline Croatia & 4.04 & 3.14 & 4.06 & 3.03 & 3.45 & 2.75 & 3.82 & 9.97 \\
\hline $\mathrm{B} \& \mathrm{H}$ & 3.93 & 2.78 & 3.57 & 2.89 & 3.90 & 3.27 & 4.40 & 2.09 \\
\hline Albania & 3.91 & 2.40 & 2.41 & 2.95 & 2.28 & 3.86 & 3.32 & 0.00 \\
\hline Serbia & 3.87 & 2.49 & 3.62 & 2.32 & 3.23 & 3.07 & 3.90 & 0.00 \\
\hline $\begin{array}{l}\text { Western } \\
\text { Balkans }\end{array}$ & 3.99 & 2.82 & 3.47 & 2.82 & 3.29 & 3.34 & 3.81 & 2.27 \\
\hline Austria & 5.22 & 5.02 & 5.09 & 4.79 & 4.89 & 3.82 & 4.71 & 144.62 \\
\hline Slovenia & 4.34 & 3.86 & 4.80 & 3.36 & 3.89 & 3.14 & 3.82 & 66.05 \\
\hline Hungary & 4.30 & 3.45 & 5.13 & 2.74 & 4.30 & 3.13 & 4.37 & 22.08 \\
\hline Bulgaria & 4.27 & 3.20 & 3.53 & 2.88 & 3.00 & 3.45 & 3.61 & 3.61 \\
\hline Romania & 4.07 & 3.06 & 3.43 & 2.90 & 3.08 & 3.08 & 3.83 & 1.89 \\
\hline Greece & 3.86 & 2.75 & 3.33 & 2.42 & 2.86 & 2.66 & 5.20 & 9.44 \\
\hline $\begin{array}{l}\text { EU } \\
\text { neighbours }\end{array}$ & 4.34 & 3.56 & 4.22 & 3.18 & 3.67 & 3.21 & 4.26 & 41.28 \\
\hline$E \cup 27$ & 4.74 & 4.07 & 4.75 & 3.87 & 4.37 & 3.62 & 4.52 & 79.98 \\
\hline
\end{tabular}

Source: Global Competitiveness Report 2012-2013, World Economic Forum

Figure 7 gives a comparative view of the $12^{\text {th }}$ pillar of $\mathrm{GCl}$ (Innovation) according to its sub-pillars for the observed groups of countries.

The diagram shows that the Western Balkan countries are at considerable disadvantage compared with the EU neighbours with respect to capacity for innovation and the quality of scientific research institutions. This emphasizes the necessity of placing universities and research institutions in the centre of economic and technological development in the Western Balkan countries. 
Despotović D. et al.: Innovativeness and Competitiveness of the Western Balkan...

Judging by the criterion of capacity for innovation, the difference between the EU neighbours and the EU27 is obvious.

Figure 7. A comparative view of the $12^{\text {th }}$ pillar of the $\mathrm{GCl}$ (Innovation) according to its sub-pillars for 2012

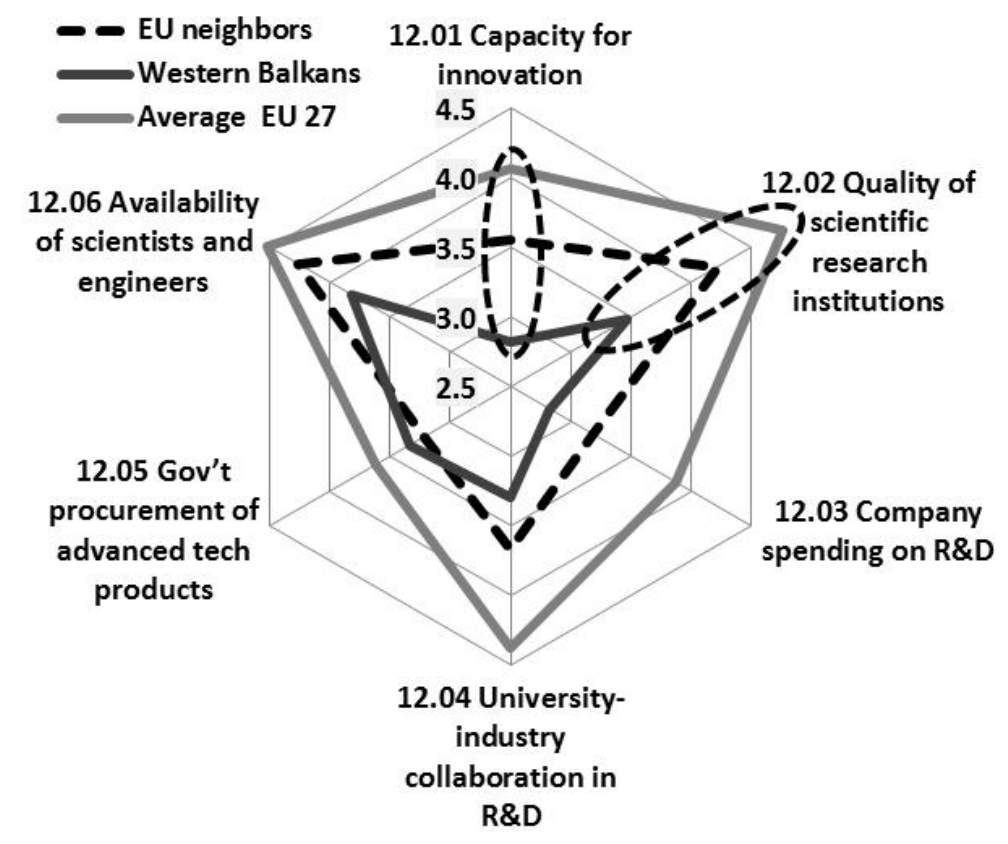

Source: Author

\section{Correlation between the global innovation index and the global competitiveness index among the Western Balkan countries and the selected EU member states}

The correlation between economy's innovativeness and country's competitiveness was observed with the help of regression and correlation analysis. Since the analysis encompassed mutual linear correlation between two variables, simple linear regression and correlation analysis methods were used here. Regression analysis served the purpose of identifying the appropriate linear correlation among variations of the observed indicators. Correlation analysis was used with the purpose of investigating the quantitative match among variations of the observed indicators. Figures 8 and 9 show dispersion diagrams and linear form of correlation between the Global 
Despotović D. et al.: Innovativeness and Competitiveness of the Western Balkan...

Innovation Index and the Global Competitiveness Index for the observed groups of countries in 2012.

Figure 8. Dispersion diagram and linear correlation between the global innovation index and the global competitiveness index for the Western Balkan countries in 2012

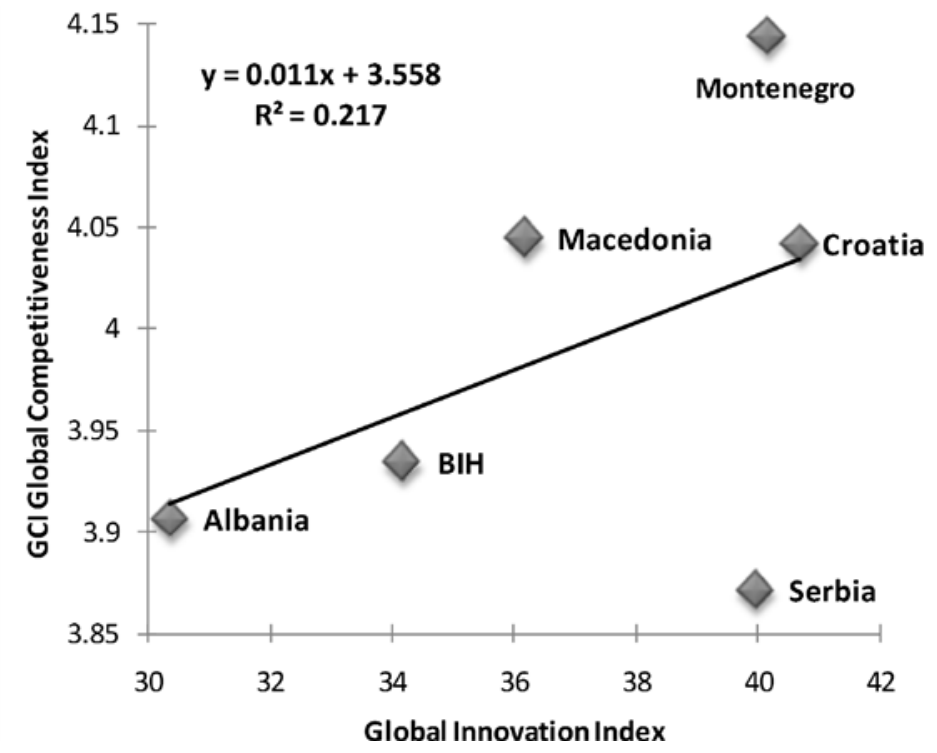

Source: Author

Graphic presentation of variable data pairs of the Global Innovation Index and the Global Competitiveness Index for the selected countries shows a very weak correlation between the variations of the observed variables. Customization of the linear form of correlation and analysis of the specified model components also points to the previously stated and visually perceived statement. In fact, linear regression function has the following form: $y=3.558$ $+0.011^{*} X$, with statistical values $R^{2}=0.217$ and $R=0.466$. The value of the coefficient of determination points to the fact that only $21.7 \%$ of variations of the variable Global Competitiveness Index is explained by the variations of the variable Global Innovation Index, whereas the remaining $78.3 \%$ stands for the result of the impact of other factors not included in this model. The value of the correlation coefficient equalling 0.466 also points to a weak correlation. The value of this coefficient illustrates the existence of a weak, direct (straight line extending from the lower left to the upper right corner of the graph) linear correlation among the observed variables of the sampled countries. The slope of the line $\left(b_{1}=0.011\right)$ indicates that the growth of the Global Innovation Index by one unit of measurement implies the growth of the Global Competitiveness 
Despotović D. et al.: Innovativeness and Competitiveness of the Western Balkan...

Index by 0.011 (in corresponding units of measurement used for expressing the variable Global Competitiveness Index). Examination of hypothesis of the linear correlation between the observed variables by using the appropriate regression coefficient indicates the value of the test statistic equalling 1.0309. With the probability of the significance level equalling 0.05 and the threshold 2.7764 , it can be concluded that there is no statistically significant linear correlation between the Global Innovation Index and Global Competitiveness Index variables.

Figure 9. Dispersion diagram and the linear form of correlation between the global innovation index and the global competitiveness index for the selected EU member states in 2012

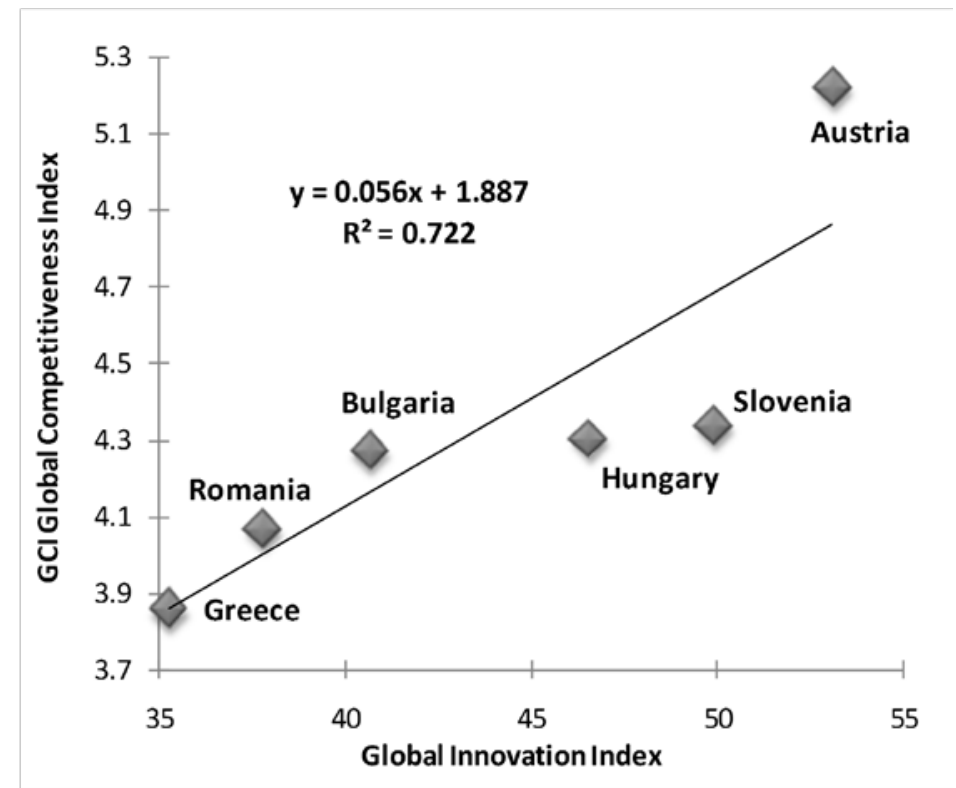

Source: Author

Graphic presentation of variable data pairs of the Global Innovation Index and the Global Competitiveness Index for the selected EU member states shows a strong correlation between the variations of the observed variables. Customization of the linear form of correlation and the analysis of the specified model components also points to the previously stated and visually perceived statement. Linear regression function has the following form: $y=$ $1.887+0.056^{\star} X$, with statistical values $R^{2}=0.722$ and $R=0.849$. The value of the coefficient of determination illustrates that only $72.2 \%$ of variations of the variable Global Competitiveness Index is explained by the variations of the 
Despotović D. et al.: Innovativeness and Competitiveness of the Western Balkan...

variable Global Innovation Index, whereas the remaining $27.8 \%$ stands for the result of the impact of other factors not included in this model. The value of the correlation coefficient equalling 0.849 also points to a strong correlation. The value of this coefficient indicates the existence of a strong, direct (straight line extending from the lower left to the upper right corner of the graph) linear correlation among the observed variables of the sampled countries. The slope of the line $\left(b_{1}=0.056\right)$ points to the fact that the growth of the Global Innovation Index by one unit of measurement implies the growth of the Global Competitiveness Index by 0.056 . Examination of hypothesis of the linear correlation between the observed variables by using the appropriate regression coefficient indicates the value of the test statistic equalling 3.237. With the probability of the significance level equalling 0.05 and the threshold 2.7764, it can be concluded that there is statistically significant linear correlation between the Global Innovation Index and Global Competitiveness Index variables.

\section{Conclusion}

On the basis of the conducted empirical research, it is possible to formulate the following conclusions:

- The Western Balkan countries are at a disadvantage compared with the European Union member states with respect to innovativeness. The highest potential of the Western Balkans lies in human resources and still respectable scientific outputs. Development of these potentials should be the focus of all activities aimed at strengthening innovativeness and competitiveness. Institutions and infrastructure represent the critical "input" factors of competitiveness and innovativeness of the Western Balkan countries. For that reason, it is necessary to stabilize institutions, improve infrastructure and stabilize political landscape in the region. The acceptance of the European Union standards is the best way of achieving these goals.

- Consideration of the correlation between the Global Innovation Index and the Global Competitiveness Index among the Western Balkan countries showed that there was no statistically significant impact (linear correlation) of the Global Innovation Index on the Global Competitiveness Index. Consideration of the correlation between these variables among the EU member states surrounding the Western Balkans pointed to a strong, direct linear correlation and the statistically significant impact (linear correlation) of the Global Innovation Index on the Global Competitiveness Index. 
Despotović D. et al.: Innovativeness and Competitiveness of the Western Balkan...

\section{References}

Almunia, J. (2010) How competitive is the European Union, The Global Competitiveness Report, 2010-2011. Geneva: World Economic Forum within the framework of the Centre for Global Competitiveness and Performance

Cvetanović, S. Mladenović, I. \& Despotović, D. (2012) Technological innovations in the long wave cycle theories, TTEM, Vo. 7. No 1, Sarajevo, pp. 237-244, ISSN 1840-1503

Cvetanović, S. Mladenović, I. \& Nikolić, M. (2011) Teorijske osnove koncepta inovacionog kapaciteta privrede, Ekonomika, Niš, 57 (4), pp. 14-23.

Cvetanović, S., Despotović D., \& Nedić V. (2012). Comparative Analysis of Business Sophistication of Serbia and Its Neighboring Countries, Industrija, Vol. 40, No. 4, pp 89-106.

Gibson, D. V., \& Naquin, H. (2011). Investing in innovation to enable global competitiveness: The case of Portugal. Technological Forecasting and Social Change, 78(8), 1299-1309.

Hasan, I., \& Tucci, C.L. (2010). The innovation-economic growth nexus: Global evidence. Research Policy, 39(10), 1264-1276.

Krstić, B., \& Stanišić, T. (2013). The influence of knowledge economy development on competitiveness of southeastern Europe countries. Industrija,41(2), 151-167.

Krugman, P. (1994) "Competitiveness: A dangerous obsession", Foreign Affairs, Vol. 73. No. 2, pp. 28-44.

Krugman, P. (1996) "Making Sense of the Competitiveness Debate", Oxford Review of Economic Policy, Vol. 12. No.3, pp. 17-25.

Link, A. Siegel, D. (2003) Technological Change and Economic Performance, (London: Routledge).

Marginean, S. (2006) Competitiveness: From microeconomic foundations to national determinants, Studies in Business and Economics, Vol. 1. Issue 1, pp. 29-35.

Metcalfe, S., \& Ramlogan, R. (2008). Innovation systems and the competitive process in developing economies. The Quarterly Review of Economics and Finance, 48(2), 433-446.

Porter, M. Stern, S. (2002), National Innovative Capacity, in: Scwab, K., Porter, M., Sachs, J., eds. The Global Competitiveness Report 2001-2002, (New York: Oxford University Press).

Sener, S., Sarıdogan, E. (2011). The Effects Of Science-Technology-Innovation On Competitiveness And Economic Growth. Procedia - Social and Behavioral Sciences, Volume 24, 2011, Pages 815-828

Stefanović, Z. (2011), "Innovations as the Factor of Competitiveness and Issue of Economic Theory - An Evolutionary Approach, in: Krstić, B, ed. Improving the Competitiveness of the Public and Private Sector by Networking Competences. (Niš: Faculty of Economics), pp. 1-19.

The Global Competitiveness Report 2011-2012, World Economic Forum, Switzerland, Geneva.

The Global Innovation Index, INSEAD \&, WIPO, 2012.

Welfens, P. (2011), Innovations in Macroeconomics, Heidelberg; New York: Springer.

Zubović, J., \& Bradić-Martinović, A., (2013). Jačanje konkurentnosti kao faktor izlaska iz krize država Zapadnog Balkana, U: Institucionalne promene kao 
Despotović D. et al.: Innovativeness and Competitiveness of the Western Balkan...

determinanta privrednog rasta Srbije, Ekonomski fakultet, Univerziteta u Kragujevcu, str. 403-419. 